\section{The Impacts of}

Decentralization Policy in The Mining Sector on

\section{Human Security of Local Communities in Indonesia}

\section{Suyani Indriastuti}

1. Lecturer in International Relations Department, University of Jember, Indonesia

2. Doctoral Researcher in International Relations, University of Nottingham, United Kingdom

\section{Received: September 29, 2015/ Accepted: April 25, 2016}

\section{Abstract}

This study aims to analyse the impacts of decentralization policy in the mining sector on human security of local communities in Indonesia. This is a documentary study that employs a comparative approach. The cases examined in the study are selected within the time periods of 2010 to 2014 to reflect how the increased provincial autonomy of local government in Indonesia since 1999 has been reflected on the mining industry and its stakeholders. All local governments in Indonesia have higher authority to manage their natural resources based on regional autonomy laws. After more than ten years of the implementation of decentralization policy, however, this study finds that it has had complex impacts on economic security in different local communities, as well as threatening the environment and social security. This article identifies that the role of local government performance and democracy that is supported by revenue sharing fund affects the realisation of the human security of local communities. The significance of this research is in theoretical and empirical contributions to expand the current understanding of the relationship between decentralization policy and human security in developing countries with particular regard to the mining industry.

Keywords:Decentralization; Mining; Human Security; Indonesia

\section{Corresponding Author}

Mobile phone: +447508422146, email: s_indriastuti.fisip@unej.ac.id or Idxsi3@nottingham.ac.uk
Abbreviations:

\begin{tabular}{|lll|}
\hline BPS & $: \begin{array}{l}\text { BadanPusatStatistik(Indonesian Central } \\
\text { Agency of Statistics) }\end{array}$ \\
BKKBN & $: \begin{array}{l}\text { BadanKoordinasiKeluargaBerencana } \\
\text { Nasional (Population/ National Family }\end{array}$ \\
& $: \begin{array}{l}\text { Planning Coordinating Board) } \\
\text { CSR }\end{array}:$ Corporate Social Responsibility \\
DBH & $:$ Dana BagiHasil \\
IDI & $:$ Indonesian Democracy Index \\
UNDP & $:$ United Nations Development Programme \\
UNOCHA $:$ United Nations Office for the & Coordination of Humanitarian Affairs
\end{tabular}

\section{Introduction}

Decentralization has become a major issue in Indonesia under reforming agendas since the mid-199os [1]. It refers to the process within which 'political, fiscal and administrative power' is transferred to 'lower levels in administrative and territorial hierarchy' [2]. The 1997/1998 economic crisis had numerous spill-over effects in aspects of political and social life in the Indonesian Archipelago. In terms of politics, the crisis precipitated the fall of the Soeharto regime and the rise of a decentralization policy under Law 22/1999 on Regional Autonomy and Law 25/1999 on balanced budgets between the central and regional governments $[3,4]$.

According to these regional autonomy laws, local governments have higher authority to manage several areas such as land and natural resources in their areas. Simultaneously, the Indonesian government also reformed the fiscal scheme to grant more autonomy to local governments, whereby the latter receive an intergovernmental balanced budget from the central government under the scheme of general budget allocation (Dana AlokasiUmum, DAU), as well as receiving revenue from the mining industries that extract natural resources in their area called 'revenue sharing fund' or Dana BagiHasil(DBH) [5].

In Indonesia's New Order era, the mining sector was mainly managed by the central government, to which national revenue was directly transferred. This situation significantly changed after the fall of Soeharto, with regions (provinces and regencies) being granted more authority to manage their natural resources, as well as possessing $80 \%$ of 'revenue sharing fund' from the mining sector in their areas. Moreover, the Indonesian government also passed the Law 4/2009 on Mineral and Coal Mining, under which authority was conferred on regional governments to manage the mining sector [6]. The implementation of decentralization policy is based on expectations and calculations that decentralization will bring positive impacts on development. Regarding the impacts of decentralization, 
however, scholars have been debating whether decentralization leads to positive impacts on local communities or rather causes regresssion.

The optimistic perspectives on decentralization state that 'decentralization will increase economic efficiency' since local government has better information about local conditions due to its geographic proximity. Therefore, local government could deliver public services that match with the particular preferences of the local communities [7:244; 8]. Compared to the central government, local government could be 'more responsive' to local demands and preferences, as well as providing the best service for their constituents [9]. Moreover, optimistic arguments also argue that decentralization leads to less corruption; Fisman and Gatti (2002) argued that 'fiscal decentralization in government expenditure is strongly and significantly associated with lower corruption' [10:325].

Those arguments stand in contrast to several studies, which found that decentralization has been causing complex problems such as conflict and inequality of welfare. Previous work showsthe complexities of the implementation as well as the impacts of Indonesia's decentralization policy on local communities, in particular the mining sector. The mining sector is significant in Indonesia since it has become the main income source for some provinces, reflecting the lack of economic diversification (particularly the service sector) beyond the core Indonesian islands of Java, Bali and Sumatera. However, there are complexities regarding the implementation, as well as the outcome of the mining industries, and whether it really benefits the regions or conversely harms local communities. This argument has been discussed by several studies on mining decentralization in Indonesia. Spiegel (2012) investigated the complexity of the mining sector in Indonesia and concluded that Indonesian governments seem to be ambiguous in their implementation of decentralization. There are many overlapping powers, administrative structures and public-private interests that cause uncertainty and complexity in the mining sector [11]. This situation causes both vertical and horizontal conflicts, such as between governments and mining companies, between local people and mining companies, and among local people themselves.

Duncan (2007), in addition, argued that the implementation of regional autonomy in Indonesia provides mixed outcomes for local communities. On one side, decentralization is an opportunity for local communities to enjoy greater autonomy and (tentatively) more democracy, however this decentralization can also produce ambitions of local governments to increase their income through natural resources exploitation in a way not necessarily in the longterm interests of the local communities, putting the environment and indigenous peoples particularly at risk [2]. Indeed, recent findings about decentralization in Indonesia show a pessimismstic picture. Gandataruna and Hayson (2011) claim that the new legislation on the mining decentralization in Indonesia is 'unlikely to result in a maximum benefit to the Indonesian people' [12: 221].

Despite of those particular arguments, this article argues that previous studies have limited discussion of human security related to decentralization, particularly concerning the mining sector. Focusing on food security, Rusastra et.al. (2008) claimed that the complexity of rural development in the decentralization era poses challenges to realise food security and community development programs [13]. On the other hand, in the case of Cambodia, Bonheura \& Lane (2002) argues that environmental insecurity such as biodiversity loss is caused by 'population pressure, governance deficiency, and external factors'; natural resources are subject to conflict due to their economic value, and such conflict threatens ecological and economic sustainability [14:33]. In terms of economic security, Sepulveda \& Martinez-Vazquez (2011) argued that fiscal decentralization does not lead to positive impacts on equality and poverty reduction

Evidence in Indonesia, however, shows that after more than ten years of the implementation of the decentralization policy in particular in the mining sector, there is a decreasing poverty rate and increasing human development index. The poverty rate in different provinces, however, does not reflect a more equitable distribution of welfare from mining (and other) revenues. It would therefore be useful to assess the impacts of decentralization policy on local communities by taking the case of Indonesia, which has seen significant progress in decentralization. This paper aims to analyse the impacts ofIndonesian decentralization of the mining policy on human security of local communities in Indonesia. This paper compares several provinces in Indonesia that receive high revenue shares of funds from the mining sector. It was found that decentralization policy has mixed outcomes, increasing economic, political and food security, while threatening environmental and community (social) security. Since decentralization policy provides greater authority for local governments to manage their region, local government performance and democracy play important roles in managing the outcomes of mining decentralization policy.

The rest of this paper is organized as follows: section two of this paper talks about a human security theoretical framework that provides a measurement to assess the impacts of decentralization policy on human security. The next section is about a comparative approach for evaluating the impacts of Indonesia's decentralization policy in the mining sector on human security of local communities. Section four is data description and followed by analysis and findings in section $\mathrm{V}$.

\section{Human Security as a Conceptual Framework}

This paper aims to assess the impacts of decentralization policy in the mining sector, as well as empirically investigate the relationship between such decentralization and the human security of local communities. Human security can 
be defined as the protectionof people's survival, livelihood and dignity [15]. It is introduced by the United Nations Development Programme (UNDP)since the 1990s and consists of seven dimensions: economic, food, health, environment, personal, community and political security [16].These security dimensions pertain to human rights to freedom from fear and want, and freedom to live in dignity [15]. Freedom from fear focuses on the protection of human rights, while freedom from wants emphasizes the economic aspect that has a parallel with development.

Regarding the definition of human security, this article argues that human security is a condition within which the security and freedom of the people or individuals are guaranteed. Security means 'freedom from various risks' [17]. During its evolution, the human security idea has followed the Japanese approach that ties human security with development and the Canadian approach that focuses on human security in conflict areas. The UNDP conception of human security has become the subject of criticism due to its broad interpretation, but it also inspired both scholars and states to develop the conception of human security. In the academic sphere, scholars have been debating the concept of human security, whether challenging or supporting it. In the practical context, states have implemented human security in their policies. However, different users of the human security conception have interpreted it differently according to their own objectives, cultures or interests [18]. As a result, there are different approaches to human securiuty, namely the broad and the narrow which can be classified as the first generation of human security.

The broad view of human security is presented by the UN, in particular the UNDP and the Human Security Unit at The United Nations Office for the Coordination of Humanitarian Affairs (UNOCHA), as well as the Japanese approach. Accordingly, humans should be vouchsafed freedom from want, freedom from fear and freedom to live in dignity $[15,19]$. In-line with the UNDP perspective, the Japanese approach secures people from all kinds of violence [20] and additionally encourages people to develop means to protect themselves, such as in terms of education, equality of economic opportunity, adequate health care and the gender equality [21].

On the contrary of the broad argument, the Canadian approach that can be considered to be the narrow approach claims that HS as envisioned by the UNDP is ineffective to protect people due to its lack of precision and its failure to specify particularly vulnerable groups. Therefore, Canada campaigns for a narrower understanding of human security focused on protecting people from threats of violence [22] or granting people safety from violence and non-violent threats [17:590].
In the context of the decentralization policy in the mining sector, this paper argues that the Japanese approach to human security fits with the case in Indonesia. Accordingly, in order toachieve human security, the Japanese approach to human security places greater emphasis on freedom from want, and is mainly concerned with sustainable development. Sustainable development concerns balanced investment in long-term assets, such as stocks of capital, manufacturing facilities and infrastructure, human (socio-economic) development and natural conservation [23]. The pillars of sustainable development as envisioned by the UN are economic, social and environmental concerns[24].

Furthermore, the management of the mining sector in Indonesia must be in line with regulations stated in the 1945 Constitution of the Republic of Indonesia, Article 33 (3): 'the land, the waters and the natural resources within shall be under the powers of the State and shall be used to the greatest benefit of the people' [25]. It means that natural resources must be managed by the state and revenue redistributed to the people to realise human security (freedom from want, from fear, and to live in dignity). Indeed, as stated in the Law of the Republic Indonesia no. 4/2009 concerning the mining sector, mining has to be managed under the principle of sustainable development and environmental protection to achieve the prosperity of the people [6].

Yet, the notion of sustainable development serve a framework for investigating the impatcs of decentralization policy in the mining sector on sustainable human security achievement as shown in the following table 1. 
Table 1 Indicators and Mechanism for Sustainable Human Security of Local Communities

\begin{tabular}{ll}
\hline Human Security Dimensions and Indicators & $\begin{array}{l}\text { Mechanism to Enhance Sustainable Human Security of Local } \\
\text { Communities (with regard to mining sector) }\end{array}$ \\
\hline
\end{tabular}

Economic Fabric

- Fulfilment of basic human needs

- Job opportunities

- Poverty reduction

- Security from economic shocks
Distributed mining revenue and CSR to local communities in order to:

- Assured access to basic human needs

- Provided availability of public and private employment

- Encourage self-employment

- Provided government financed social safety nets

\section{Environment Fabric}

Environmental protection from natural damage, degradation of the local ecosystem and

biodiversity, pollutions (air, water and sound)
- Provided sustainable regulations and practices with regards to natural resources and environmental degradation.

- Response mechanism including early warning for natural hazards and disasters

Social Fabric (education, food, health, personal/ peacefulness)

- Education: availability and accessible education centre, literacy rate

- Food: available and accessible healthy food, people's ability to buy and/ or to produce food

- Health: life expectancy, availability and accessible of health centre

- Personal/ peacefulness: human rights protection and the absence of direct violence
- Prioritize budged allocation to education for establishing facilities and empowering people

- Food entitlement by assuring the availability and accessible of food by the people

- Allocating budget for health facilities and service, promoting health insurance, interconnected system of surveillance of the disease.

- Enforce protection of people without discrimination, in particular vulnerable people

Source: Compiled from a review of [26], [27], [28]

From the perspective of the Japanese approach, human security is tied to development, and places development, particularly the economic aspect, at the heart of human security. More generally, it can be argued that 'freedom is the principal end of development as well as its primary means' [15:18] within which 'progress in one area enhances the chances of progress in the other' [29:23].

In this sense, human security refers to protecting and empowering people from various menaces threatening human life, such as poverty and environmental degradation [30]. It deals with the fulfillment of the fundamental human needs, increasing standards of living and solving poverty problems. These are the constituents of giving humans the security of freedom from want. More specifically, the Japanese approach tohuman security covers the protection of global environment, eradication of poverty and hunger and guaranteeing human dignity [31: 235-236], as well as the achievement of health and welfare of populations [32: 528].

It can be said that poverty is the core of human problems. Therefore, in terms of the freedom from want in the human security idea, people have to be free from poverty. Poverty has caused complex spill-over effects for the worst situations, such as low education, low standards of health, and causing social problems. Poverty should be meantin a broader sense than only income, and it can be seen as 'a deprivation of basic capabilities, rather than merely as low income' [34: 20]. However, low income is the main contributor in causing poverty since it is 'a strong predisposing condition for an impoverished life' [33:87]. Therefore, poverty should be measured under a generalized poverty scheme, in order to tentatively quantify persons living 'below the pre-defined threshold of any component areas of well-being' [17:594]

This article measures human security based on a set of well-being domains. In the sense of human security, wellbeing refers to the condition within which human security is realized. It should reflect freedom from the three aspects of poverty, inequality and vulnerability [34]. More specifically, it includes income, health, education, environment or biodiversity, political freedom and democracy [17: 598]. This poverty and its spillover effects on health, food, and education are affected by political freedom and democracy. Political freedom and democracy provide a possibility for people to influence decision making process that affects people's lives. It also affects the distribution of welfare that might provide inequality and vulnerability of people. One of the indicators of political freedom and democracy is implementing free and fair elections, as well as political participation of people. Based on these indicators, human insecurity can be understood as a condition within which people live below the threshold of the domains. Regarding the terminology of the UNDP's human security, 
economic security, food security, health security, environment security, and political security are threatened by poverty, hunger and famine, injury and disease, pollution, resource depletion, environmental degradation and political repression [28].

\section{Comparative \\ Approach \\ as Methodology}

This article employs a comparative approach to consider 'where to compare, how to compare and what to compare' [35: 289-291]. There are several steps in this comparative approach, including analysing and identifying the research question, identifying and operationalizing the variables, case selection, constructing a case codebook, code-write cases and comparison [36]. Following these steps, firstly, the article aims to identify the impacts of decentralization policy in the mining sector on human security of local communities in Indonesia. The article also aims to identify under what conditions decentralization policy in the mining sector effectively promotes human security of local communities in Indonesia. Based on this question, the independent variable is decentralization policy in the mining sector, while the dependent variable is human security of local communities in Indonesia.

\subsection{Operationalization}

The variables of this study can be operationalized as follows. The operationalization of decentralization policy in the mining sector is derived from the Law 32/2004 on Regional Autonomy, Law 33/2004 on the Balanced Budget between Central and Regional Government, and Law 4/ 2009 on Mineral and Coal Mining. Decentralization in the mining sector is operationalized as: (1) the authority of local governments to issuing the mining permits, producing regional regulation on mining; (2) the rights of local governments to receive and manage $80 \%$ of revenue from the mining sector in their area; and (3) the authority of local governments to manage and monitor the mining sector in their area $[6,37,38]$. Based on these rights, it can be claimed that the authority of all local governments in Indonesia under the Reformation regime since 1999 has been high.

In terms of the dependent variable of human security, in particular freedom from want, it can be operationalized as a set of well-being domains that includes income, health, education, environment or biodiversity, political freedom and democracy[17: 598]. Regarding these domains, this article argues that not all domains have a quantitative threshold of their indicators, but some of them should be measured qualitatively. The World Bank (2011) defines individuals' poverty based on monetary and non-monetary aspects. In terms of monetary aspect, the World Bank proposes a threshold of individual's poverty as living with purchasing power of less than USD 2 per day. The amount is mainly purchased for individuals' daily needs such as food, clothes, and shelter, which in turn affects non-monetary aspects such as health and education. It is also argued that 'poverty is associated not only with insufficient income or consumption, but also to insufficient outcomes with respect to health, nutrition, and literacy' [39]. People with enough income can purchase qualitatively and quantitatively better food by which their food security is guaranteed. The poverty also has a parallel with health and education conditions. Health can be measured based on life expectancy and people's health states. Meanwhile, education is measured based on the level of literacy and the average years of schooling [17: 6oo]

This article only uses secondary data provided by institutions such as BadanPusatStatistik (BPS) or 'Indonesian Central Agency of Statistics' and NGOs. In terms of the freedom from want, this article uses poverty data and the human development indices (HDI) of the selected provinces provided by BPSdue to its internal, construct and external validity.

BPS data, particularly concerning poverty rate and human development index (HDI), has fulfilled internal validity requirements. The information used by BPS is based on the results of the 'National Social Economic Survey (SurveiSosialEkonomiNasional/ SUSENAS)Kor', which in 2013 sampled about 300,ooo households (of the total 64,041,200 households) across 497 districts in Indonesia. This sample is representative as it includes rural and urban households in Western and Eastern Indonesia[4o].

In terms of construct validity, data provided by BPS matches the concept of human security, in particular freedom from want (the ability to fulfill basic human needs). In this respect, BPS measures poverty rate based on consumption of the household to meet basic human needs, including food and nonfood (e.g. education, health, clothes and housing). The components of HDI measured by BPS consists of health (life expectancy), education (mean years of schooling and literacy rate), and the standard quality of life. These components investigated by BPS reflects the level of freedom from want of the local communities. In this sense, HDI is useful for investigating human security since it is based on health, education and standard of living dimensions[29].

Meanwhile, in terms of external validity, BPS data on poverty rate is similar to the results of a survey conducted by the State Ministry for Population/ National Family Planning Coordinating Board (BadanKoordinasiKeluargaBerencana Nasional/ BKKBN), as shown in table 2. Triangulation of these data suggests that the BPS data are valid. They are also accessible per year, enabling comparison of data in a time series to make generalizations. In terms of the methods of measuring HDI, BPS is parallel with the methods used by the UNDP, which means that BPS uses methods that widely accepted worldwide.

Furthermore, it is a tenet of neoliberalism that freedom from want can be realized in regions that allow political participation of the people. This article uses data from the 
Indonesian Democracy Index (IDI) provided by Coordinating Minister for Political, Legal, and Security Affairs in cooperation with BPS. IDI emphasizes democracy on how people have opportunity to benefit from the political freedom, i.e. civil liberty, political rights, and institutions of democracy [41: 13].

\subsection{Case Selection}

Furthermore, in terms of case selection in the comparative approach, this study uses a 'most different' design, which is characterized by case similarities in terms of the independent variable (decentralization policy), but differences in terms of the intervening variables (e.g., capacity of government and the contribution of the mining industries) [42]. Regarding the case selection, the study proposes several criteria. Firstly, the selected provinces are managing the mining sector, as well as receiving revenue from the mining industries, in particular the non-oil and gas mining sectors, because Indonesia has numerous mineral resources, of which oil and gas are managed by the central government, while the rest (e.g. gold, copper, coal, tin, bauxite and nickel) are managed by local governments.

In addition, this essay selects the provinces that have a high revenue sharing fund or DBH. DBH is transferred by central government to the local governments who have the mining projects in their geographical area. Law No. 33/2004 on balanced budgets between the central and regional governments states that regional governments have the rights of $80 \%$ of the revenue produced by the mining company in their area [38]. It consists of land rent and royalties of mining production. The provinces selected in this essay are the nine highest revenue sharing fund receivers that had DBH of hundreds of millions of rupiahs per year in 2010, including provinces of South Sumatera, Bangka Belitung, West Kalimantan, Central Kalimantan, South Kalimantan, East Kalimantan, West Nusa Tenggara, North Maluku and Papua [43].
The selected cases are provinces that have different performance or capacity. Based on the Indonesian Governance Index (2008, 2012), which assesses the performance of 33 provinces in Indonesia [44], this essay classifies the performance of the government according to performance rankings: high (rank 1-11), medium (rank 12-22) and weak (rank 23-33). This study selects provinces categorized as having low, medium and high performance in 2012. This article, therefore, classifies South Sumatra, South Kalimantan, and Bangka Belitung as having a high performance. Meanwhile the medium performance consists of Central Kalimantan, West Nusa Tenggara, and East Kalimantan. Lastly, West Kalimantan, Papua, and North Maluku are considered as having low performance of governance.

In addition, poverty is the main crucial threat for human security since it brings spillover negative effects on human security, such as on food security, health and education. Therefore, this article investigates the rate of poverty in the selected provinces. The average poverty rate in Indonesia by 2013 was $11.47 \%$ [45]; thus a high provincial poverty rate is defined as more than $11.47 \%$ of the population being above the poverty line and vice-versa. Meanwhile, the average of human development index in Indonesia is 68.31. Therefore, a high provincial human development index can indicate higher than 68.31, and vice-versa.

\section{Data Description}

The data used in assessing the impacts of decentralization policy on human security of local communities, as well as investigating the conditions under which decentralization leads to human security, are drawn from several sources. The following table provides a data description to support the analysis. Table 2 provides data about the authority of local government based on regional autonomy law, revenue sharing fund, the amount of gross Regional Domestic Product (RDP), performance of local government and democracy index.

Table 2Performance of Local Governance, Democracy, Revenue Sharing Fund, and Gross Regional Product

Selected Provinces
Revenue Sharing Fund 2010

(IDR)
Gross Regional

Domestic Product 2010
Democracy Index of the Provinces 2011

(IDR billion)

$\begin{array}{cc}\text { South Sumatra } & \text { High (rank 6) } \\ \text { South Kalimantan } & \text { High (rank 7) } \\ \text { Bangka Belitung } & \text { High(rank 11) } \\ \text { Central Kalimantan } & \text { Medium(rank 12) } \\ \text { West Nusa Tenggara } & \text { Medium (rank 19) } \\ \text { East Kalimantan } & \text { Medium (rank 22) } \\ \text { West Kalimantan } & \text { Low }(\text { rank 26) }\end{array}$

404,366,719,597

$1,538,188,559,890$

171,117,230,201

$119,128,681,421$

$227,312,562,099$

3,397,985,015,902

$291,772,354,733$

$157,735.04$
$59,823.07$
$26,712.97$
$42,571.11$
$49,631.65$
$321,764.43$
$60,541.58$

67.92

66.47

67.13

76.28

54.49

66.37

74.86 


\begin{tabular}{|c|c|c|c|c|}
\hline Selected Provinces & $\begin{array}{l}\text { Performance of } \\
\text { Government } 2012\end{array}$ & $\begin{array}{c}\text { Revenue Sharing Fund } 2010 \\
\text { (IDR) }\end{array}$ & $\begin{array}{c}\text { Gross Regional } \\
\text { Domestic Product } \\
2010 \\
\text { (IDR billion) } \\
\end{array}$ & $\begin{array}{c}\text { Democracy Index } \\
\text { of the Provinces } \\
2011\end{array}$ \\
\hline South Sumatra & High (rank 6) & $404,366,719,597$ & $157,735.04$ & 67.92 \\
\hline Papua & Low(rank 29) & $1,358,136,103,354$ & $87,733.42$ & 59.05 \\
\hline North Maluku & Low(rank 33) & $124,762,394,324$ & $5,389.83$ & 59.17 \\
\hline
\end{tabular}

Source: [44, 43, 45, 41]

Table 3 (below) is about human security of local communities in terms of the poverty rate. As mentioned previously, this data was validated by triangulation, whereby if the results of the second test are similar, it can be assumed that the findings of the research are valid. In this sense this article compares data of poverty rate provided by BPS with BKKBN.

Table 3 Poverty Rate of Local Communities(BPS and BKKBN 2011, 2012, 2013)

\begin{tabular}{|c|c|c|c|c|c|c|}
\hline \multirow[t]{3}{*}{ Selected Provinces } & \multicolumn{6}{|c|}{ Poverty Rate } \\
\hline & \multicolumn{3}{|c|}{ BPS (\%) } & \multicolumn{3}{|c|}{ BKKBN (\%) } \\
\hline & 2011 & 2012 & 2013 & 2011 & 2012 & 2013 \\
\hline South Sumatra & 13.95 & 13.48 & 14.06 & 14.24 & 13.78 & 14.24 \\
\hline South Kalimantan & $5 \cdot 35$ & 5.01 & 4.76 & 5.29 & 5.06 & 4.77 \\
\hline Bangka Belitung & 5.16 & $5 \cdot 37$ & 5.25 & 5.75 & $5 \cdot 53$ & 5.21 \\
\hline Central Kalimantan & 6.64 & 6.19 & 6.23 & 6.56 & 6.51 & 5.93 \\
\hline West Nusa Tenggara & 19.67 & 18.02 & 17.25 & 19.73 & 18.63 & 17.97 \\
\hline East Kalimantan & 6.63 & 6.38 & 6.38 & 6.77 & 6.63 & 6.06 \\
\hline West Kalimantan & 8.48 & 7.96 & 8.74 & 8.6 & 8.17 & 8.24 \\
\hline Papua & 31.24 & 30.66 & 31.53 & 31.98 & 31.11 & 31.13 \\
\hline North Maluku & 10.00 & 8.06 & 7.64 & 9.18 & 8.47 & 7.5 \\
\hline
\end{tabular}

Source: $[45,46]$

Table 3 shows that BPS and BKKBN produced similar findings. It means that due to its validity, this article can use BPS data as the basis of analysis. Furthermore, it is also necessary to compare poverty rate before and after the implementation of decentralization policy. Table 4 (below) uses BPS data for comparing the poverty rate in Indonesia before and after decentralization; it can be seen that there has been a slight reduction since the implementation of the decentralization policy, although this correlation does not necessarily indicate causality.

Table 4 Comparison of poverty rate before and after implementation of decentralization policy

\begin{tabular}{|c|c|c|c|c|c|c|}
\hline \multirow[t]{2}{*}{ Selected Provinces ${ }^{\bullet}$} & \multicolumn{6}{|c|}{ Poverty Rate } \\
\hline & 1993 & 1996 & 1999 & 2011 & 2012 & 2013 \\
\hline South Sumatra & 14.89 & 15.89 & 23.53 & 13.95 & 13.48 & 14.06 \\
\hline South Kalimantan & 18.61 & 8.53 & 14.57 & $5 \cdot 35$ & 5.01 & $4 \cdot 76$ \\
\hline Bangka Belitung & - & - & - & 5.16 & $5 \cdot 37$ & 5.25 \\
\hline Central Kalimantan & 20.85 & $13 \cdot 50$ & 15.06 & 6.64 & 6.19 & 6.23 \\
\hline West Nusa Tenggara & $19 \cdot 5^{2}$ & 31.97 & 32.96 & 19.67 & 18.02 & 17.25 \\
\hline East Kalimantan & 13.75 & $9 \cdot 73$ & 20.16 & 6.63 & 6.38 & 6.38 \\
\hline West Kalimantan & 25.05 & 24.21 & 26.17 & 8.48 & 7.96 & 8.74 \\
\hline Papua & - & - & - & 31.24 & 30.66 & 31.53 \\
\hline North Maluku & - & - & - & 10.00 & 8.06 & 7.64 \\
\hline
\end{tabular}

Source:[47, 48, 49, 50]

Bangka Belitung, Papua, and North Maluku are new provinces in Indonesia established in the decentralization era 
As noted earlier, human security in particular freedom from want is also related with the aspects of health, education, and economy as shown in the human development index, and the level of inequality. Therefore, the following table 5 serves the data of human development index (HDI) and Gini ratio

Tabel 5 Human Development Index and Gini Ratio

\begin{tabular}{|c|c|c|c|c|c|c|}
\hline \multirow[t]{2}{*}{ Selected Provinces } & \multicolumn{3}{|c|}{ HDI } & \multicolumn{3}{|c|}{ Gini ratio } \\
\hline & 2011 & 2012 & 2013 & 2011 & 2012 & 2013 \\
\hline South Sumatra & 73.42 & 73.99 & $74 \cdot 36$ & 0,34 & 0.40 & 0.383 \\
\hline South Kalimantan & 70.44 & 71.08 & 71.74 & 0.37 & 0.38 & 0.359 \\
\hline Bangka Belitung & $73 \cdot 37$ & $73 \cdot 78$ & 74.29 & 0.30 & 0.29 & 0.313 \\
\hline Central Kalimantan & 75.06 & $75 \cdot 46$ & 75.68 & 0.34 & 0.33 & 0.350 \\
\hline West Nusa Tenggara & 66.23 & 66.89 & 67.73 & 0.36 & 0.35 & 0.364 \\
\hline East Kalimantan & 76.22 & 76.71 & $77 \cdot 33$ & 0.38 & 0.36 & 0.371 \\
\hline West Kalimantan & 69.66 & 70.31 & 70.93 & 0.40 & 0.38 & 0.396 \\
\hline Papua & $65 \cdot 36$ & 65.86 & 66.25 & 0.42 & 0.44 & 0.442 \\
\hline North Maluku & 69.47 & 69.89 & 70.63 & 0.33 & 0.34 & 0.318 \\
\hline
\end{tabular}

Source: [52, 51]

\section{Analysis and Finding}

Based on the data presented in the preceding tables, this article assumes that regional autonomy laws in the mining sector could become a milestone for local government to obtain human security, in particular by getting income for increasing the welfare of the local community. Regional autonomy laws in the era of Reformasiprovide great authority to all local governments in Indonesia. Due to the laws, local governments play important roles in managing their regions. However, the data show that there are different impacts of decentralization on human security in different provinces.

Table 2 shows that based on regional gross domestic product and annual revenue sharing fund from the mining sector, the richest regions among those selected provinces are East Kalimantan, Papua and South Kalimantan. Meanwhile, the lowest level of provincial democracy indexes belongs to West Nusa Tenggara, Papua and Maluku. Table 3 shows that the selected provinces with the highest poverty rates are Papua, West Nusa Tenggara and South Sumatera. These provinces are categorized as having low, medium, and high performance of local government. Moreover, Papua also has the lowest level of human development index and the highest ratio of inequality.

This paper identifies mixed conditions under which decentralization in the mining sector leads to human security. In the first group of high performance of local government, the table shows that the provinces have different levels of human security. South Sumatra has more than double the amount of revenue sharing fund of Bangka Belitung, but it has a higher poverty rate and lower human development index. A similar case occurs in the second class of the medium performance of local government, i.e., human security of West Nusa Tenggara province, as reflected by its high rate of poverty and low human development index, which are weaker than Central Kalimantan.

Nevertheless, the facts derived from the comparison between South Kalimantan, East Kalimantan and Papua that ranked as high, medium, and low respectively show that the role of local government performance is significant in determining the welfare of people. They are three provinces that receive the highest amount of revenue sharing fund in Indonesia. This article identifies the significant roles of government performance and democracyas an intervening variable that affects the effectiveness of decentralization policy in the mining sector in realizing human security. Based on the comparison, it can be said that the effectiveness of the decentralization policy to support human security is much more dependent on the performance of regional governments to manage their natural resources and to distribute the economic benefits of this to all citizens, as well as the opportunities of local government to participate in decision making process and to control the accountability of government.

This argument is supported by particular facts that East Kalimantan, with the highest revenue sharing fund and the medium rank of local government performance, has a lower poverty rate and higher human development index. A similar condition also occurs in South Kalimantan, i.e. high performance of regional government and high revenue sharing fund, leading to the low level of poverty rate and high level of human development index. In contrast, Papua has a lower rank of provincial governance performance, and a very high poverty rate and lower human development index compared to South Kalimantan and East Kalimantan.

From the perspective of economic aspects, the contribution of the mining sector on regional income does not automatically translate into improved welfare. Moreover, mining revenue is influenced by by the fluctuation of raw mineral prices. The facts imply that a high contribution of the mining sector might be effective to realize human security with the proviso that local governments have the capacity to manage the mining sector for achieving human security, but at face value it can be concluded that economic diversification (i.e. less reliance on mining) is more conducive to general economic prosperity..

However, in terms of environmental aspects, these regions have similar problems. The characteristic of 
extractive industries, in particular mining, is to cause environmental degradation [53]. Indeed, it also threatens the availability of resources for future generations.A study conducted by Limbong et.al. (2003) in Indonesia shows that there has been serious potential threats to health and environment due to mining activity[54]. Similar with this claim, Bose-O'Reilly, et al. (2010) finds that the use of mercury in mining activity in Indonesia in particular by small scale miners have threatens health and environment[55]. Health and emvironment issues might increase in line with the authority to issue mining liscences. In this respect, good governance becomes the primary conditions for enhancing mining sector to positive impatcs on human security of local communities. More specifically, In order to minimize the adverse impacts of such activities, mining firms have to be subject to rules or guidance by which the environment can be protected.

However, if, politically, decision makers might often pursue short-term tactics to increase economic growth without considering long-term impacts and sustainable development and diversification [56]. Indeed, this is quite hard if the local government and the mining industries employ illegal acts such as bribery and corruption. The Corruption Eradication Commission of Indonesia states that during the last 11 years (i.e. the operationalization of regional autonomy), there has been an increasing trend in corruption involving the heads of regional governments [57].

In terms of social aspects such as education, health, and food security, increasing economic security might brings positive direct and indirect effects on these aspects. However, negative impacts on environment also threatens food and health security. In this sense, there is a dilemma of management between economy and environment aspect. Indeed, mismanagement of mining sector by in particular government could trigger horizontal and vertical conflicts.McCharty (2004) claimed that decentralization, in particular the case of Central Kalimantan, has caused 'insecurity and heightened resource conflicts' [58]. Similarly, Peluso (2007) also emphasized the danger of decentralization in management resources that has been causing violence [59]. The mining sector, moreover, is related with 'sense of belonging' of local communities [60:21] as there has always been awareness among local communities that they have rights, albeit dormant, to benefit from natural resources in their area. Consequently, there has been increasing popular demands for the government to realise this dimension of human security, in particular since the 1990s. If this 'sense of belonging' to natural resources has been threatened, it might lead to social conflict whether horizontal or vertical. In the sense of human security, violence and conflicts reflect human insecurity, since they undermine freedom from fear.

\section{Conclusion}

Decentralization policy in the mining sector is the key for local governments to optimize their rights to manage as well as gaining benefit from their natural resources. Due to the decentralization policy, local governments have right to issuing mining permits, monitoring, as well as evaluating the mining sectors. However, mining decentralization has a mixed impatcs on human security. In terms of freedom from want, decentralization in the mining sector brings positive impacts on economic security, as shown by the decreasing poverty rate. However, other issues of human security are quite challenging in the mineral extraction, in particular related with environment, health and social issues. Health and environmental problems cause fear among local communities. From the perspective of freedom from fear, the mining sector has the potential to cause fear from illness and disaster, and direct violence through social conflicts. It can be said that mining decentralization will bring positive impatcs on human security of local communitiesisinfluenced by its circumstances in particular the role of government (top down approach) and active participation of the citizen (bottom up approach).

Local governments, particularly in the developing world, covet the (often illusory) economic contributions they expect to follow from mining sector development to increase their economic growth. Based on the analysis, this essay concludes that from top down approach, decentralization policy in the mining sector leads to the achievement of human security with the proviso of a high local governments' performance to manage their region in particular mining revenue and CSR. Following a bottom up approach, the government's roles in enhancing mining sector to positive impacts on human security need supports from stakeholeders through a democratizatic scheme. In this respect, decentralization in the mining sector will lead to human security of local communities through protection and empowerment framework.

Although this paper is based on documentary research within which the availability of data is limited, this paper can provide a basis for further research. This article is heavily reliant on documents and data provided by the Indonesian government and NGOs. Therefore, further investigation or fieldwork should investigate human security from the perspective of local communities, i.e., how the people perceive their security in relation with decentralization in the mining sector.

\section{Acknowledgements}

The author would like to thank to Directorate General of Higher Education (Ministry of Research, Technology, and Higher Education) Indonesia, University of Jember Indonesia, School of Politics and International Relations University of Nottingham, and The Institute of Asia and Pacific Studies (IAPS) University of Nottingham United Kingdom for their funding support and the facilities in doing research. 
For their supports, critiques and suggestions, the author would also like to thank toDr. Pauline Eadie, author's supervisors, sustaiN Society, the reviewers, and the panellists and audience in the International Conference on Sustainable Future for Human Security 2015.

\section{References}

[1] Booth, A., 2003. Decentralisation and poverty alleviation in Indonesia. Environment and Planning C: Government and Policy, Volume 21, pp. 181 - 202.

[2] Duncan, C. R., 2007. Mixed Outcomes: The Impact of Regional Autonomyand Decentralization on Indigenous EthnicMinorities in Indonesia. Development and Change, 38(4), p. $711-733$.

[3] Republic of Indonesia, 1999, Law no 22/1999 on Regional Autonomy. Jakarta: Government of Indonesia

[4] Republic of Indonesia, 1999, Law no 25/1999 on Balanced Budgets between the Central and Regional Governments. Jakarta: Government of Indonesia

[5] Lewis, B. D., 2001. The New Indonesian Equalization Transfer. Bulletin of Indonesian Economic Studies, 37(3), p. 325-43.

[6] Republic of Indonesia, 2009, Law no 4/2009 on Mineral and Coal Mining. Jakarta: Government of Indonesia

[7] Davoodi, H. \& Zou, H.-f., 1998. Fiscal Decentralization and Economic Growth: A Cross-Country Study. Journal of Urban Economy, Volume 43, pp. 244-257.

[8] Iimi, A., 2005. Decentralization and economic growth revisited: an empirical note. Journal of Urban Economics, Volume 57, p. 449-461.

[9] Oates, W. E., 1999. An Essay on Fiscal Federalism. Journal of Economic Literature, Volume XXXVZZ, pp. 1120-1149 .

[10] Fisman, R., \& Gatti, R. (2002). Decentralization and corruption: evidence across countries. Journal of Public Economics, 83, 325345 .

[11] Spiegel, S. J., 2012. Governance Institutions, Resource Rights Regimes, and the Informal Mining Sector: Regulatory Complexities in Indonesia. World Development, 40(1), p. 189205.

[12] Gandataruna, K. \& Haymon, K., 2011. A dream denied? Mining legislation and the Constitution in Indonesia. Bulletin of Indonesian Economic Studies, 47(2), pp. 221-231.

[13] Rusastra, I. W., Thompson, G., Bottema, J. T., \& Baldwin, R. (2008). Food Security and Poverty in the Era of Decentralization in Indonesia . CAPSA Working Paper No. 102. Jakarta: UNESCAP-CAPSA .

[14] Bonheura, N., \& Lane, B. D. (2002). Natural resources management for human security in Cambodia's Tonle Sap Biosphere Reserve . Environmental Science E Policy 5, 33-41.

[15] Sen, A. (2014). Birth of A Discourse. In M. M. Owen, Rotledge Handbook of Human Security. London: Cambridge.

[16] The UNDP, 2014. Human Development Report: Technical Notes. [Online]

Available at: http://hdr.undp.org/ [Accessed 259 2015].

[17] King, G. \& Murray, C. J., 2001. Rethinking Human Security. Political Science Quarterly, 116(4), pp. 585-610.

[18] Gasper, D., 2014. Human Security: From Definitions to Investigating a Discourse. In: M. Martin \& T. Owen, eds. Routledge Handbook of Human Security. London and New York: Routledge, pp. 28-42.

[19] Wheeler, D., 2011. Freedom from Want, and Freedom from Fear. Journal of Human Security, 7(1), pp. 37-52.
[20]Er, L. P., 2006. Japan's Human Security in Southeast Asia. Contemporary South East Asia, 28(1), pp. 141-229.

[21] McFarlane, S. N. \&Khong, Y. f., 2006. Human Security and the UN: a Critical History. Bloomington: Indiana University Press.

[22] MacLean, G., 2002. Building on a legacy or bucking tradition? Evaluating. Canadian Foreign Policy Journal, 9(3), pp. 65-83.

[23] Loomis, T. M. (2000). Indigenous Populations and Sustainable Development: Building on Indigenous Approaches to Holistic, Self-Determined Development. World Development, 28(5), 893 - 910.

[24] United Nations, 2007. Indicators of Sustainable Development: Guidelines and Methodology, New York: United Nations Publication.

[25] Republic of Indonesia, the 1945 Constitution of the Republic of Indonesia, available

at www.setneg.go.id/images/stories/kepmen/legal_product/uud_1 945.pdf [accessed 25 3 16]

[26] Azapagic, A. (2004). Developing a framework for sustainable development indicators for the mining and minerals industry. Journal of Cleaner Production, 12, 639-662.

[27] Hasting, D. D., 2013. The Human Security Index: Pursuing enriched characterization of development. Development, 56(1), pp. 66-78

[28] The UNOCHA, 2009. Human Security in Theory and Practice. New York: the United Nations.

[29] The UNDP, 1994. Human Development Report 1994, the UNDP \&Oxford: Oxford University Press.

[30] Duffield, M., 2007. Development, Security, and Unending War: governing the world of peoples. 1st ed. Malden: Politiy Press.

[31] Edstrom, B., 2008. Japan and the challenge of Human Security: The Founding of a New Policy 1995-2003. Stockholm: Institute for Security and Development Policy.

[32] Larrinaga, M. D. \& Doucet, M. G., 2008. Soverign Power and the Biopolitics of Human Security. Security Dialogue, 39(5), pp. 517537.

[33] Sen, A. (1999). Development as Freedom. Oxford: Oxford University Press.

[34] The WB. (2011). Home: Measuring Poverty. Retrieved 9 14, 2015, from The World Bank: http://web.worldbank.org/

[35] Feldman, E. J., 1978. Comparative Public Policy: Field or Method?. Comparative Politics, 10(2), pp. 287-305.

[36] Kaarbo, J. \& Beasley, R. K., 1999. A Practical Guide to the Comparative Case Study Method in Political Psychology. Political Psychology, 2o(2), pp. 369-391.

[37] Republic of Indonesia, 2004, Law no 32/2004 on Regional Autonomy. Jakarta: Government of Indonesia

[38] Republic of Indonesia, 2004, Law no 33/2004 on Balanced Budget between Central and Regional Government. Jakarta: Government of Indonesia

[39] The WB. (2011). Home: Measuring Poverty. Retrieved 9 14, 2015, from The World Bank: http://web.worldbank.org/

[40]BPS. (2015). PusatKatalog Data Micro: Indonesia-Survey SosialEkonomiNasional 2013 KorGabungan, available at http://microdata.bps.go.id/mikrodata/index.php/catalog/220 . Accessed: 27316 ]

[41] Rauf, M., Hidayat, S., Gismar, A. M. \& Mulia, S. M., 2011. Index Democracy Indonesia 2011, Jakarta: Coordinating Minister for Political, Legal, and Security Affairs in cooperation with BPS.

[42] Burnham, P., Gilland, K., Grant, W. \& Layton-Henry, Z., 2004. Research Methods in Politics. New York: Palgrave Macmillan.

[43] EITI. (2012). EITI Reconciler's Report 2010-2011 Mining Sector. Jakarta: EITI Indonesia. 
[44] Kemitraan, 2012. Indonesia Governance Index 2012, Jakarta: The Partnership for Governance Reform.

[45] BPS. (2015). Home: Poverty. Retrieved 9 19, 2015, from Number and Percentage of Poor People, Poverty Line, Poverty Gap Index,: http://www.bps.go.id/

[46]BKKBN. (2014). Data E Informasi: Data Kependudukan. Retrieved from Jumlah dan Persentase Penduduk Miskin Nasional: http://www.bkkbn.go.id/

[47] BPS. (1998). Statistical Indonesia Yearbook 1998. Indonesia: BPS

[48]BPS. (1999). Statistical Indonesia Yearbook 1999. Indonesia: BPS.

[49]BPS. (2012). Statistical Yearbook of Indonesia 2012. Indonesia: BPS.

[50] BPS. (2014). Statistical Yearbook of Indonesia. Indonesia: BPS.

[51] BPS. (2016). Beranda: Kemiskinan. Retrieved from Gini Ratio Menurut Provinsi Tahun 1996, 1999, 2002, 2005, 2007-2013: http://www.bps.go.id/linkTabelStatis/view/id/1493

[52] BPS. (2016). Beranda: Index Pembangunan Manusia. Retrieved from Indeks Pembangunan Manusia Menurut Provinsi, 19962013: http://www.bps.go.id/

[53] DTE, n.d. Home: Campaigns. [Online] Available at: http://www.downtoearth-indonesia.org/ [Accessed 14 2015].

[54]Limbong et.al. (2003). Emissions and environmental implications of mercury from artisanal gold mining in north Sulawesi, Indonesia. The Science of the Total Environment 302, 227-236.

[55] Bose-O'Reilly, S., Drasch, G., Christian Beinhoff, S. R.-F., Roider, g., Lettmeier, B., Maydil, A., . . . Siebert, U. (2010). Health Assesment of Artisanal Gold Miners in Indonesia. Science of the Total Environment, 408, 713-72

[56] Ross, M. L. (1999). The Political Economy of the Resource Curse. World Politics 51.2 , 297-322.

[57] KPK (Corruption Eradication Commission), 2015. News: Makin Banyak Kepala daerah Korupsi (There is an Increasing Number of Corruption Involving Head of Regional Government). [Online] Available at: $\underline{\text { http://www.kpk.go.id/ }}$ [Accessed 279 2015].

[58] McCharty, J. F., 2004. Changing to Gray: Decentralization and the Emergence of Volatile Socio-Legal Configurations in Central Kalimantan, Indonesia. World Development, 32(7), p. 1199-1223.

[59]Peluso, N. L., 2007. Violence, Decentralization, and Resource Access in Indonesia. Peace Review: A Journal of Social Justice, 19(1), p. 23-32.

[6o]Devi, B., \& Prayogo, D. (2013). Mining and Development in Indonesia: An Overview of theRegulatory Framework and Policies. IM4DCAction Research Report. International Mining fo Development Centre 